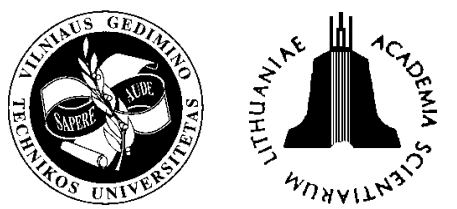

\title{
RESEARCH INTO THE APPLICATION OF BIODIESEL IN THE TRANSPORT SECTOR OF LITHUANIA
}

\author{
Sergejus Lebedevas ${ }^{1}$, Andrius Vaicekauskas ${ }^{2}$ \\ Klaipèda University Maritime Institute, I. Kanto g. 7, LT-92123 Klaipéda, Lithuania, \\ E-mail: ${ }^{1}$ laivum@ji.ku.lt; ${ }^{2}$ andrius@swelbalt.lt \\ Received 27 December 2005; accepted 28 March 2006
}

\begin{abstract}
The material of this publication presents the results of a complex research into the application of standard rapseed methyl ester (RME) and new types of biodiesels produced from waste of vegetable oil and animal fat in the transport sector of Lithuania. The analytical analysis of physical, chemical and thermodynamical properties of biodiesels is performed and its results are evualated during the formation of tasks of experimental motor tests and research into mathematical modelling. Their influence for the paramaters of a working process and exploiting characteristics such as power, fuel economy, reliability and harmful emission of gases is evaluated.
\end{abstract}

Keywords: biodiesel, physical, chemical and thermodynamical properties, working process, ecological parameters.

\section{Introduction}

The solution of ecological problems on the international level strongly influences the development of new technologies, especially of a transport sector. The problem of "Greenhouse effect" related to the emission of $\mathrm{CO}_{2}$ gases and environmental air pollution with harmful components of exhaust gases charges competitive international and national organizations to regulate and owners of transport fleets to reduce the harmful emission of exhaust gases to environment. The emission from transport means is regulated by various EU regulations, and their requirements are always strengthening: EURO standards for road transport, ANNEX VI of MARPOL 73/78 convention for the ships, EU Directive 2000/25/EC for non-road transport. One of the actual ways of solving this problem is the application of biodiesel in a transport sector. EU Directive 2003/30/EC also mentions the actuality of this solution which promotes the application of biodiesels and other alternative fuels in a transport sector with growing tendencies: $5,75 \%$ of total fuel consumption by 2010 year and $20 \%$ by 2020 year. The replacement of mineral fuel by biodiesel is one of the most effective ways for solving the problem of saving and effective usage of energetic resources which actuality is accented in 2005-06-22 EU document "Green paper on energy efficiency" and EU Directive COM 739 final 2003/0300 (COD) on energy end- use efficiency and energy services. One of the main tools for the development of biofuel technologies is incitement of a scientifical research in this area and further introduction of its results. This is reflected in priority areas of researches of national and international (FP6, FP7, EUREKA) programs. Maintaining fleets of diesel engines of Eastern Europe and Lithuania in such case consists mainly of morally old types of engines produced in 80'ies - 90'ies of the last century and most of them are not longer produced. Because of this problem the significant consumption of biodiesel in a transport sector on a country level is necessarily related to the modernisation of diesel engines for work on alternative fuels.

One of the researches into biodiesel fuel in Lithuania under the international program EUREKA is the project "BIOWASTEFUEL.E!3234", which is supported by the Lithuanian governmental foundation of science and studies. The Lithuanian and Polish institutions are involved in a scientific research of the project. Scientific researches in Lithuania are carried out by the Lithuanian Agricultural University (LAU prof. P. Janulis) and the Maritime Institute of Klaipeda University (MI KU). The main target of the work is the research into production technologies of a new type of biodiesels produced from animal and vegetable waste fats and technologies of the application of new and standard types of biodiesel (RME) in main- 
taining fleets of diesel engines in Lithuania.

This publication is the first from the planned series, where the results of the researches of technologies of the application in maintaining fleets of diesel engines attended by MI KU will be presented. The main target is the development of scientific and practical recommendations for transference of maintained in Lithuania fleets of diesel engines for work on biodiesel. A wide range of interconnected technical questions must be solved for the transference of diesel engines to work on biodiesel and the main of them are: the hold of load, fuel consumption and reliability characteristics, the optimisation of regulating parameters of engines, the development of the manual of adaptability of fuel systems to biodiesel and the maintenance manual etc.

\section{Comparative analysis of physical, chemical and thermodynamical properties of biodiesel}

For the formation of the main tasks and aspects of experimental and mathematical modelling research it is necessary to evaluate the difference of physical, chemical and thermodynamical properties of biodiesel from mineral diesel fuel and its influence for technical-economical and ecological parameters of an indicating process.

Biodiesel can be defined as liquid fuel, produced from biological feedstocks: vegetable oil, animal fat, used fried oil for the application in a diesel engine. Biodiesel and its blends with diesel fuel usually is marked with B letter and figure which means the percent part of biodiesel in the blend, for example: B100 pure biodiesel, B30 - blend with $30 \%$ of biodiesel.

The feedstock of biodiesel consists of triglyceride molecules, which structure consists of three fatty acids with long chains of carbon - from 8 to 22, connected to glycerol. Chemical and physical properties of biodiesel mostly depend on fatty acids of feedstock, because each fatty acid is characterised by its own properties.

Even one and the same type of biodiesel significantly differs depending on feedstock or a production type. It is an important factor for solving the biodiesel application problem on a country level and in Lithuania.

A biodiesel production process is named transesterification - it is the reaction of triglyceride molecules with alcohol using catalysts $\mathrm{KOH}, \mathrm{NaOH}$ or $\mathrm{NaOCH} 3$, the products of the reaction are esters of acid fats and glycerine. The main aim of transesterification is the reduction of viscosity, because viscosity of feedstocks of biodiesel is much higher than diesel fuel and its direct application in a diesel engine leads to the sediments in the cylinder of a diesel engine and the problems at the flow of fuel at low temperatures. Other alcohols can be used for a transeterification process, such as: ethanol, propanol or izopropanol, but methanol is the cheapest and mostly used in practice.

Short abreviatures for biodiesels are created depending on the feedstock of biodiesel and the type of alcohol used in the production process, for example: rapeseed methyl ester - RME, rapeseed ethyl ester REE, soybean methyl ester - SME, tallow methyl ester TME etc.

The fuel produced for the application in a diesel engine must meet a certain level of requirements as diesel fuel ensuring a high level of technical-economical and ecological parameters. The standard LST EN 14214:2003 is applied for biodiesels in Lithuania.

The comparative analysis of physical, chemical and thermodynamical properties of biodiesels are presented below.

Elemental composition of fuel. Fuel for internal combustion engines consists of 3 basic chemical elements: carbon $-\mathrm{C}$, hydrogen $-\mathrm{H}_{2}$ and oxygen $-\mathrm{O}_{2}$ (Table 1):

- the part of oxygen in biodiesel is from 10,3 up to

Table 1. Elemental composition of fuel

\begin{tabular}{|c|c|c|c|c|c|}
\hline & Diesel fuel No 2 & Rapeseed oil & TME & RME & SME \\
\hline $\mathrm{C}, \%$ & $86,3[1]$ & $77,6[1]$ & 75,15 [3]; 76,42 [4] & 77 [1]; 78,7 [4] & 78 [6]; 76,25 [3] \\
\hline $\mathrm{H}, \%$ & $13,7[1]$ & $11,5[1]$ & $13,11[3] ; 12,59[4]$ & 12,1 [1]; 12,66 [4] & $11,7[6] ; 12,59[3]$ \\
\hline $\mathrm{O}_{2}, \%$ & $0[1]$ & $10,9[1]$ & $11,74[3] ; 10,98[4]$ & $10,9[1] ; 9,22$ [4] & $10,3[6] ; 11,16[3]$ \\
\hline $\mathrm{S}, \%$ & $<0,03[1]$ & $0,01[2]$ & $0,01[4]$ & 0 [1]; 0,012 [4] & $<0,005[6]$ \\
\hline $\mathrm{N}_{2}, \mathrm{ppm}$ & - & - & $\begin{array}{c}9[4] \\
77[5]\end{array}$ & $10[4]$ & $29[6]$ \\
\hline $\mathrm{P}, \mathrm{ppm}$ & $0[1]$ & - & $44[5]$ & $50[1]$ & $20[7]$ \\
\hline
\end{tabular}


$11,74 \%$ compared to up to $1 \%$ in diesel fuel, because of that a combustion process is organised with higher value of excess air ratio; the increase of oxygen in the fuel improves a combustion process reduces the emission of non-combusted products $(\mathrm{CO}, \mathrm{CH}$, soot), but at the same time increases the emission of nitric oxides $\mathrm{NO}_{\mathrm{x}}$, which is one of the most toxic of emission gases;

- the increase of oxygen part in biodiesels is related to the reduction of quantities of $\mathrm{C}$ and $\mathrm{H}$ : biodiesel consists of $\mathrm{C}-75,2 \div 78 \%$ and $\mathrm{H}_{2}-$ $11,7 \div 13,11 \%$ and these portions are lower compared to mineral diesel fuel where $\mathrm{C}-85 \div 87 \%$, $\mathrm{H}_{2}-12,5 \div 14,7 \%$; this factor causes the lower calorific value of biodiesel because oxygen is ballast in fuel and $\mathrm{C}$ and $\mathrm{H}$ are sources of energy;

- the composition of biodiesel differently than mineral diesel fuel is propertied by a low level of sulphur $(0 \div 0,02 \%)$, which is one of the problems of harmful emission and engine parts corrosion for diesel engines;

- the quantity of phosphorus is determined because of its negative influence on catalytic converters used in control equipment of theemission of exhaust gases in vehicles;

- the quantity of nitrogen shows the quality of biodiesel, because the presence of nitrogen shows a not-completed process of cleaning biodiesel after production.

Fractional composition of fuel determines the groups of compounds of which the fuel consists. It is determined by ranges of temperatures when different fractions of fuel vaporises. Fractional composition of fuel influences the process of formation of fuel-air mixture in the cylinder of a diesel engine.

Fractional composition of biodiesel is simpler as compared with diesel fuel, because it consists of six or seven esters of fatty acids [10] (Table 2). Narrow fractional composition of biodiesels is viewable by the range of temperature of vaporisation, for example: RME $299-346{ }^{\circ} \mathrm{C}$, mineral diesel fuel No 2: $177,8-$ $345{ }^{\circ} \mathrm{C}$. The temperature of the beginning of vaporisation is significantly higher than of mineral diesel fuel. The temperature of vaporisation of $90 \%$ of diesel fuel is regulated by standards and for diesel fuel No 2 it must be lower than $282{ }^{\circ} \mathrm{C}$, for the biodiesel the temperature of vaporisation of $95 \%$ of fuel is regulated by Czech (CSN 65 6507) and Italy (UNI 10635) national standards of biodiesels $\leq 360^{\circ} \mathrm{C}$.

Vegetable oils are distributed by the speed of vaporisation starting from the highest as follows [11]: coconut oil, palm oil, sunflower oil, rapeseed oil, silk oil, flax oil. Methyl esters of vegetable oils vaporise as monocomponental compounds with a long period of heating.

Minimal temperature of vaporisation and its range together with cetane number directly influence the formation of fuel-air mixture and dynamics of the first phase of combustion, what in turn influences the dynamics of a work process and the formation of harmful emission and this must be evaluated at motor tests of biodiesels.

Calorific value is the quantity of heat energy, which is emitted by fuel at the time of combustion under set conditions of the experiment. Lower calorific value is applied to internal combustion engines which evaluate the loses of heat for the vaporisation of water appeared because of the oxidation of hydrogen of fuel. This heat can be emitted only at the time of condensation of vapours in exhaust gases following the limits of a diesel engine. Calorific value is directly related to elemental composition of fuel. Lower calorific value $H_{U}$ is determined experimentally or by a widely used in practise formula of Mendelejev:

$H_{U}=\frac{\left(81 C^{M}+246 H^{M}-30\left(0^{M}-S^{M}\right)-6\left(W^{M}+9 H^{M}\right)\right)}{4,19}$,

Table 2. Ranges of vaporisation of fuel

\begin{tabular}{|l|c|c|c|c|}
\hline & Diesel fuel No 2 & TME & RME & SME \\
\hline Temperature of start of vaporisation of fuel, ${ }^{\circ} \mathrm{C}$ & $177,8[8]$ & $324,4[8]$ & $299[9]$ & $326[9]$ \\
\hline $\mathrm{T} 10,{ }^{\circ} \mathrm{C}$ & $211,7[8]$ & $278,9[8]$ & $328[9]$ & $340[9]$ \\
\hline $\mathrm{T} 50,{ }^{\circ} \mathrm{C}$ & $261,1[8]$ & $341,1[8]$ & $336[9]$ & $344[9]$ \\
\hline $\mathrm{T} 90,{ }^{\circ} \mathrm{C}$ & $316,7[8]$ & $351,7[8]$ & $340[9]$ & $348[9]$ \\
\hline Temperature of the end of vaporisation of fuel, ${ }^{\circ} \mathrm{C}$ & $345,0[8]$ & $361,1[8]$ & $346[9]$ & $366[9]$ \\
\hline NOTE: T10...T96 - vaporised part of mass of fuel, $\%$ & & \\
\hline
\end{tabular}


where $H_{U}$ - lower calorific value, $\mathrm{kJ} / \mathrm{kg} ; C^{M}, H^{M}$, $O^{M}, S^{M}, W^{M}-$ mass portions of fuel elements, $\mathrm{kg} / \mathrm{kg}$ fuel.

Lower calorific values of biodiesel and mineral diesel fuel are presented in Table 3. Calorific value of vegetable oils and its alcohol esters is lower than diesel fuel because of oxygen [12], which portion in biodiesels is $10-12 \%$ (Table 1 ). The difference of calorific value of biodiesels and diesel fuel is $12-13 \%$. Lower calorific value determines higher fuel consumption, because for ensuring of the same load (torque) it is necessary to combust more biodiesel. Calorific value of diesel fuel depends on the quantity of aromatic hydrocarbons in the fuel, which calorific value is not higher than other fraction, but its higher density depends on the total calorific value of fuel. Biodiesels consist of esters of fatty acids with a different degree of saturation. A lower degree of saturation of esters of fatty acids determines lower calorific value [12]. The density of biodiesel is higher than diesel fuel $-8 \%$ and this compensates lower calorific value. Additional influence for the compensation of lower calorific value of biodiesel makes higher viscosity - reduces the leakage of fuel in plunger pair of a high pressure fuel pump [12].

The density and viscosity are fuel properties which mostly influence the process of fuel injection.

Fuel density for the diesel fuel is determined at $15^{\circ} \mathrm{C}$ (see Table 4 ). The density of biodiesel at $15^{\circ} \mathrm{C}$ is $0,86-0,90 \mathrm{~g} / \mathrm{cm}^{3}$ [17] and it is $2-7 \%$ [2] higher value compared to diesel fuel $\left(0,82-0,85 \mathrm{~g} / \mathrm{cm}^{3}\right.$ [13]). This factor positively influences the saving characteristics of the load of a diesel engine on the same level for the transference of diesel fleets for work on biodiesel with- out additional regulation of units of a fuel supplying system.

Fuel viscosity is regulated by the standards at $40{ }^{\circ} \mathrm{C}$ (see Table 5). Viscosity dependence on temperature is a very important characteristics of each fuel, because transport means are exploited in a wide range of climatic conditions. Viscosity of fuel influences the injection of fuel, the quality of filtering and fuel supply through tubes. Viscosity decreases with the decrease of temperature, it influences the decrease of the quality of fuel injection, what in turn increases the emission of non-combusted products and decreases the quality of lubrication conditions of diesel parts. The viscosity of vegetable oils is significantly higher than of mineral diesel fuel and it is the main reason why they are not directly applied in diesel engines as fuel and the aim of transesterification is to lower the viscosity of vegetable oils. Kinematic viscosity of biodiesel at $40{ }^{\circ} \mathrm{C}$ is $4,0-$ $6,2 \mathrm{~mm}^{2} / \mathrm{s}$ and it is twice higher than diesel fuel viscosity $2,4-2,6 \mathrm{~mm}^{2} / \mathrm{s}$ [12]. The viscosity of biodiesel depends on feedstock, the viscosity of rapeseed oil and biodiesel is higher than of soybean oil and soybean biodiesel. Higher viscosity of biodiesel decreases the leakages of fuel in a plunger pair and in turn it changes the parameters of a fuel supply process: injected quantity of fuel, real advanced angle of fuel injection what directly influences an indicating process and harmful emission of exhaust gases.

The dependence of viscosity of biodiesel on temperature must be taken into account for solving the tasks of practical application of biodiesels, because at lower than $273 \mathrm{~K}$ temperature the viscosity of biodiesel significantly increases and the reason of it is the crystallisation of saturated methyl esters.

Table 3. Calorific values of fuel

\begin{tabular}{|l|c|c|c|c|c|}
\hline & Diesel fuel No 2 & Rapeseed oil & TME & RME & SME \\
\hline Lower calorific value, MJ/kg & $43,44[10]$ & $37,62[1]$ & $37,25[4]$ & $\begin{array}{c}36,80[12] \\
37,30[9]\end{array}$ & $\begin{array}{c}37,26[6] \\
37,04[4]\end{array}$ \\
\hline
\end{tabular}

Table 4. Density of fuel

\begin{tabular}{|c|c|c|c|c|c|}
\hline & Diesel fuel No 2 & Soybean oil & TME & RME & SME \\
\hline Density at $15{ }^{\circ} \mathrm{C}, \mathrm{g} / \mathrm{cm}^{3}$ & $0,82 \div 0,85[13]$ & $0,92[14]$ & $0,876[9]$ & $0,883[9]$ & $\begin{array}{r}0,884[16] \\
0,889[6]\end{array}$ \\
\hline
\end{tabular}

Table 5. Viscosity of fuel

\begin{tabular}{|c|c|c|c|c|c|c|}
\hline & Diesel fuel No 2 & Rapeseed oil & Soybean oil & TME & RME & SME \\
\hline $\begin{array}{c}\text { Kinematic viscosity } \\
\text { at } 40{ }^{\circ} \mathrm{C}, \mathrm{cst}\end{array}$ & $2,4 \div 2,6[12]$ & $37,3[14]$ & $33,1[14]$ & $\begin{array}{c}4,1[15 \\
4,8[9]\end{array}$ & $\begin{array}{c}4,83[20] \\
4,83[9]\end{array}$ & $\begin{array}{c}4,08[16] \\
4,01[6]\end{array}$ \\
\hline
\end{tabular}


Cetane number is a characteristic of fuel which shows the ability of self ignition in the cylinder of a diesel. It is determined experimentally in a standard one cylinder engine. Cetane number depends on fuel composition and influences the start of a diesel, the beginning of the process of combustion, equal work of a diesel and the emission of exhaust gases. For the constant regulation of a diesel engine the negative influence will be made by a too early phase of fuel injection (increase of mechanical load of parts of cylinder-liner group, increase of $\mathrm{NO}_{\mathrm{x}}$ emission) and a too late phase (decrease of fuel economy, increase of smoke in exhaust gases).

Cetan number of biodiesel is higher than of diesel fuel. By the data of EPA (Enviromental pollution agency, USA) the middle value of cetan number of biodiesels is 55 and for diesel fuel this parameter is 44 [18]. The big difference is fixed not only for different types of biodiesels but also and for the same type of biodiesel (see Table 6). Cetan number of biodiesel depends on fatty acids of feedstock [10]. A longer chain and higher saturation of fatty acids define higher value of cetan number. The oxidation of biodiesel also defines higher value of biodiesel: after the rise of peroxide value up to 82 , cetan number increases by $7-8$ points, further increase of peroxide value does not increase the cetan number [19].

Temperatural parameters of fuel. The ability to flow at low temperatures is an actual problem of diesel and biodiesel fuels. There are used three temperatural characteristics: Cloud Point, Pour Point and Cold Fil- ter Plugging Point. Cloud Point is the temperature when fuel starts to crystallise what depends on the blocking of a fuel filter. Pour Point is the temperature when fuel stops to flow. For the evaluation of fuel properties at low temperatures in Europe test EN 116:1981 Cold Filter Plugging Point is common which identifies the temperature at which wax or other crystals (first observed at the Cloud Point) can stop the flow of fuel by plugging the engine's fuel filter.

The parameters of low temperature of biodiesels are worse than of diesel fuel. Clound point of biodiesel seeks $-4 \div+12{ }^{\circ} \mathrm{C}$ (see Table 7). Pour Point of biodiesel is $-3,8 \div+9^{\circ} \mathrm{C}$. Fuel properties at low temperatures mostly depend on molecular structure and saturation of compounds. A longer chain of fatty acid and a higher degree of saturation depend on a higher level of Cloud Point and Pour Point. The characteristics of low temperature of biodiesel produced from animal fats are worse than of biodiesels of vegetable oils origin because of the mentioned problem - a higher degree of saturation [20].

Regarding the said above one of the main tasks of the practical application of biodiesel in the exploitation is improving of its characteristics at a low temperature.

Flash Point is the characteristic of safe use of fuel, which determines the lowest temperature at which the application of the test flame causes the vapour above the sample to ignite. Flash Point of biodiesel and mineral diesel fuel is presented in Table 8 .

Table 6. Cetan number of fuel

\begin{tabular}{|c|c|c|c|c|c|c|c|c|}
\hline & \multicolumn{3}{|c|}{ Diesel fuel } & \multirow{2}{*}{ Rapeseed oil } & \multirow{2}{*}{ Soybean oil } & \multirow{2}{*}{ TME } & \multirow{2}{*}{ RME } & \multirow{2}{*}{ SME } \\
\hline & No 2 & GOST $305-823$ & EN 590 & & & & & \\
\hline $\begin{array}{l}\text { Cetan } \\
\text { number }\end{array}$ & $\begin{array}{c}40 \div 45[12] \\
45,8[10]\end{array}$ & $>45[21]$ & $>51$ & $37,5[2]$ & $38,1[2]$ & $\begin{array}{c}58,0[15] \\
58,8[9]\end{array}$ & $\begin{array}{c}48 \div 61,8[19] \\
52,9[9]\end{array}$ & $\begin{array}{c}46,2[16] \\
45 \div 67[19] \\
50,9[9]\end{array}$ \\
\hline
\end{tabular}

Table 7. Parameters of low temperatures of fuel

\begin{tabular}{|c|c|c|c|c|c|c|}
\hline & Diesel fuel No 2 & Rapeseed oil & Soybean oil & TME & RME & SME \\
\hline Cloud Point, ${ }^{\circ} \mathrm{C}$ & $-25 \div-15$ & $-3,9[7]$ & $-3,9[7]$ & $\begin{array}{c}+12[15] \\
+13,9[9]\end{array}$ & $\begin{array}{c}-1[1] \\
-4[9]\end{array}$ & $\begin{array}{c}+2[7] ;-0,5[9] \\
+1[7]\end{array}$ \\
\hline Pour Point, ${ }^{\circ} \mathrm{C}$ & & $-31,7[7]$ & $-12,2[7]$ & $\begin{array}{c}+9[9] \\
+16[4]\end{array}$ & $\begin{array}{c}-10,8[9] \\
-15[4]\end{array}$ & $\begin{array}{c}-3,8[9] \\
-4[7]\end{array}$ \\
\hline $\mathrm{CCFP},{ }^{\circ} \mathrm{C}$ & $-10 \div-20[10]$ & - & - & $11[10]$ & $-12[1]$ & $-2[7]$ \\
\hline
\end{tabular}

Table 8. Flash Point of fuel

\begin{tabular}{|c|c|c|c|c|c|c|c|}
\hline & \multicolumn{2}{|c|}{ Diesel fuel } & \multirow{2}{*}{ Rapeseed oil } & \multirow{2}{*}{ Soybean oil } & \multirow{2}{*}{ TME } & \multirow{2}{*}{ RME } & \multirow{2}{*}{ SME } \\
\hline & No 2 & EN 590 & & & & & \\
\hline Flash Point, ${ }^{\circ} \mathrm{C}$ & $60-80$ [13] & 55 [48] & 246 [7] & 254 [7] & $\begin{array}{l}117[9] \\
160[4]\end{array}$ & $\begin{array}{l}170[9] \\
179[4]\end{array}$ & $\begin{array}{l}131[9] \\
188[4]\end{array}$ \\
\hline
\end{tabular}


The highest value of Flash Point belongs to biodiesels of vegetable oils because they don't have light fractions. Transesterification significantly lowers the value of Flash Point. Flash Point of biodiesels is higher than of diesel fuel. The value of Flash Point is limited by standard LST EN 14214 and it is $>120^{\circ} \mathrm{C}$ so we can conclude that the safety of biodiesel is ensured.

Stoichieometric air/fuel ratio $L_{0}$ shows the minimum quantity of air which is necessary for the combustion of $1 \mathrm{~kg}$ of fuel and it is calculated by the formula:

$L_{0}=\frac{1}{0,21}\left(\frac{C^{M}}{12}+\frac{H^{M}}{4}-\frac{S^{M}+O^{M}}{32}\right) ; \mathrm{kmol} / \mathrm{kg}$ fuel,$(2)$ where $C^{M}, H^{M}, O^{M}, S^{M}$ are mass portions of elements in fuel, $\mathrm{kg} / \mathrm{kg}$ fuel.

As we can see from that stoichieometric air/fuel ratio of biodiesel will be lower than of diesel fuel because $11 \%$ of oxygen is present in the composition of biodiesiel. Excess air ratio l will be higher for biodiesel because of lower value of stoichieometric air/fuel ratio of fuel combustion for the same external conditions and regulation of diesel, as a result the conditions for the full combustion of fuel will be ensured $[22,23]$.

Iodine value is the characteristic which shows the level of unsaturation of fuel (see Table 9) [24]. The high Iodine value shows the unsaturation of fuel which leads to the formation of sediments and can cause the problem of stability of fuel. Iodine value is limited by standards: German DIN V $51606-<115$, Swedish SS155436 $-<125$, when the same parameter for the diesel fuel is limited $<10$ [20]. If to compare biodiesels among themselves the highest Iodine value belongs to SME and the lowest to TME and the reason of that is a higher portion of unsaturated esters of fatty acids in the composition of biodiesels produced from animal fats [24].

The stability of fuel is characterised by 3 parameters: thermal, oxidation and storage stability. Thermal stability defines the strain of formation of sediments in fuel because of an oxidation process under changing temperatures (working conditions in a diesel engine), which cause splugging of fuel filters.

Oxidation stability defines the same strain of the formation of sediments but under atmosphere condi- tions because of the contact with air (storage characteristic). Storage stability defines the changes of fuel quality (sediments) in the case of its long term storage. The main of these characteristics is Oxidation stability which also defines the increase of water content and the growth of microbiological organisms in fuel.

Biodiesels are propertied as good solvents. One of the main problems of the exploitation of biodiesels related to the property of solvent is the strain to clean fuel tanks from sediments and to deliver it into the fuel system what causes the plugging of fuel filters. This is also an important factor for the practical application of biodiesel in the exploitation for the preparation of fuel systems.

\section{Conclusions}

1. The transference of maintained diesel fleets of Lithuania for the work on biodiesels and their blends with diesel fuel as the way of solving actual ecological and energetical problems is argued on an international level by the following facts:

- EU Directive 2003/30/EC which is promoting the application of biofuels in the EU countries where the growing tendencies of their application are set: $5,75 \%$ of total fuel consumption by 2010 year and $20 \%$ by 2020 year;

- the change of fossil diesel fuel to biodiesel is also one of the effective ways to solve the problem of saving the recourses of energy and their rational use, which actuality is mentioned in 22 June 2005 "Green paper on energy efficiency" and EU Directive COM 739 final 2003/0300 (COD) on energy end-use efficiency and energy services.

2. The importance of national decisions for the change of fossil diesel fuel to biodiesel is argued by big difference of age and characteristic of renewability of the maintained diesel fleets of Western and Eastern Europe, what charges to look for own local decisions for ensuring of commitment of the requirements of the EU Directives. The transference of morally old fleets of diesel engines for work on biodiesel requires to perform a complex research where compromise decisions must be taken regarding the change of fuel economy, harmful emission of exhaust gases and reliability.

Table 9. Iodine number of fuel

\begin{tabular}{|c|c|c|c|c|c|c|c|}
\hline & \multicolumn{2}{|c|}{ Diesel fuel } & \multirow{2}{*}{ Rapeseed oil } & \multirow{2}{*}{ Soybean oil } & \multirow{2}{*}{ TME } & \multirow{2}{*}{$\mathrm{RME}$} & \multirow{2}{*}{ SME } \\
\hline & No 1 & No 2 & & & & & \\
\hline $\begin{array}{l}\text { Iodine } \\
\text { number }\end{array}$ & $8,6[10]$ & $<6[21]$ & $\begin{array}{c}94 \div 120[24] \\
108,05[2]\end{array}$ & $\begin{array}{c}120 \div 143[24] \\
69,82[2]\end{array}$ & $35 \div 48[24]$ & $\begin{array}{c}115[1] \\
97[20] \\
97,4[9]\end{array}$ & $\begin{array}{l}131[24] \\
133[20] \\
133,2[9]\end{array}$ \\
\hline
\end{tabular}


3.Performed analytical research into physical, chemical and thermodinamical properties of biodiesels allows to conclude the following influence of these properties on the working process, technical-economical parameters and the formation of the harmful emission of exhaust gases:

- higher density and viscosity of biodiesel intesificates the injection of biodiesel which exhibits the increase of a real advanced angle of fuel injection (in the case of fixed angle of fuel injection), the duration of fuel injection decreases and dynamics of fuel torch increases (increase of speed and penetration) in the camera of combustion what in turn increases the time for fuel-air mixture formation;

- lower quantity of aromatic hydrocarbons in biodiesel blends with diesel fuel improves the characteristics of flammability what causes the decrease of duration of an induction period of combustion and the increase of a phase of beginning visible combustion;

- because of higher enthalpy of vaporisation of biodiesel a shorter period of induction decreases the portion of fuel-air mixture of a cycle prepared for the combustion; these factors compensate the increase of dynamics of an induction period (kinetic phase of combustion) related to the increase of phase of beginning of combustion; on a certain level noticed tendencies are characterised for modern diesels boosted by the medium effective pressure;

- early beginning of combustion increases the amount of heat extracted until the maximum pressure $P_{\max }$ of a cycle is reached what influences the increase of emission of nitric oxides $\mathrm{NO}_{\mathrm{x}}$;

- lower content of sulphur in the composition of biodiesel decreases the emission of sulphur oxides because it directly depends on sulphur content in the fuel;

- a positive factor which ensures the absolute level of soot formation and influences a combustion process is the presence of oxygen $\sim 11 \div 12 \%$ in the composition of biodiesel; it also increases the excess of air and improves the combustion to the complete products, intensificates the main phase of fuel combustion what in turn improves fuel economy;

- the increase of excess air ratio and the improvement of a combustion process related to oxygen content and lower stoichieometric air/fuel ratio $(\sim 13,8$ compared to diesel fuel - 14,5) negatively influences the increase of emission of nitric oxides $\mathrm{NO}_{\mathrm{X}}$ related to the rise of local temperatures in a combustion camera;
- the next negative factor of biodiesel application is the aggressiveness of biodiesel to synthetic materials;

- biodiesels have properties with worse characteristics at low temperatures.

4. The features of differences of physical, chemical and thermodynamical properties of biodiesel fuel and diesel fuel analysed in this publication are evaluated at the time of the formation of tasks of experimental motor tests and mathematical modelling research, which results will be presented in the next publications: a research into technical-economical and ecological parameters for the transference of work on biodiesel of diesel engine type F2L511 produced by company "Oruva ir Co" (Mazeikiai, Lithuania) and a research into kinetic combustion of a tractor diesel engine of type A41 etc.

\section{References}

1. Contribution to the 7th European conference on biomass for energy and environment florence, pilot project "BIODIESEL", Manfred Woergetter, Austrian Institute of Agricultural Engineering, October 1992. 7 p.

2. Demirbas, A. Biodiesel fuels from vegetable oils via catalytic and non-catalytic supercritical alcohol transesteri.cations and other methods: a survey Department of Chemical Education, Karadeniz Technical University, PK 216, Trabzon 61035, Turkey. Accepted 23 September 2002.

3. Graboski, M.; McCormick, R.; Alleman, T.; Herring, A. Effect of biodiesel composition on $\mathrm{NO}_{\mathrm{x}}$ and $\mathrm{PM}$ emissions from a DDC series 60 engine draft final report to National Renewable Energy Laboratory Contract No ACG-8-17106-02 prepared by Colorado Institute for Fuels and Engine Research Colorado School of Mines, Golden, CO 80401-1887, CSM Contract No 4-41769, December 29, 1999. 71 p.

4. Peterson, C. L.; Hammond, B.; Reec, D.; Thompson, J.; Beck, S. Performance and durability testing of diesel engines using ethyl and methyl ester. Department of Biological and Agricultural Engineering, University of Idaho, Idaho 83844-2060. 126 p.

5. Kinast, J. A. Production of biodiesels from multiple feedstocks and properties of biodiesels and biodiesel/ diesel blends, final report. National Renewable Energy Laboratory, Contract No DE-C36-99-GO10337. 18 p.

6. Scholl, K. W.; Sorenson, S. C. Combustion of soybean oil methyl ester in a direct injection diesel engine. SAE paper NO. 930934. SAE, Warrendale, PA. 1993. 13 p.

7. Knothe, G.; Dunn, R.; Bagby, M. Biodiesel: The use of vegetable oils and their derivatives as alternative diesel fuels. In: ACS Symp. Ser. 666 (Fuels and Chemicals from Biomass), American Chemical Society, Washington, DC, 1997, p. 172-208.

8. Tat, E.T. Investigation of oxides of nitrogen emissions from biodiesel-fueled engines. A dissertation submit- 
ted to the graduate faculty in partial fulfillment of the requirements for the degree of doctor of philosophy. Iowa State University Ames, Iowa, 2003.

9. Graboski, M.; McCormick, R. Combustion of fat and vegetable oil derived fuels in diesel engines. To be published in Progress in Energy and Combustion Science, 1997.

10. Prakash, C.B. A critical review of biodiesel as a transportation fuel in Canada. Prepared by GCSI - Global Change Strategies International Inc. for the Transportation Systems Branch Air Pollution Prevention Directorate Environment Canada, March, 1998. 104 p.

11. Advanced Combustion Research for Energy from Vegetable Oils (ACREVO) Project Final Report, 1998.

12. Van Gerpen, J.; Shanks, B.; Pruszko, R.; Clements, L. D.; Knothe, G. Biodiesel analytical methods, August 2002 - January 2004. National Renewable Energy Laboratory. NREL/SR-510-36240, July 2004. 95 p.

13. Shaine Tyson, K. Biodiesel handling and use guidelines. National Renewable energy laboratory. NREL/TP-58030004, September 2001. 17 p.

14. Przybylski, R. Canola oil: physical and chemical properties. Canada Publication, www.canola-council.org, 1999. $12 \mathrm{p}$.

15. Ali, Y.; Hanna, M.A.; Cuppett, S.L. Fuel properties of tallow and soybean oil esters. JAOCS, Vol 72, No 12, p. 1557, 1995.

16. Bagby, M. O.; Freedman, B.; Schwab, A. W. Seed oils for diesel fuels: sources and properties. ASAE paper No 87-1583, Amer. Soc. Agric. Engrs., St. Joseph, 1987.

17. European standard. Automotive fuels - Fatty acid methyl esters (FAME) for diesel engines - Requirements and test methods. European committee for standardization, October 2002. 13 p.

18. A comprehensive analysis of biodiesel impacts on exhaust emissions. Draft technical report. United States Environmental Protection Agency, EPA420-P-02-001. October 2002. $118 \mathrm{p}$.

19. Van Gerpen, J. Cetane number testing of biodiesel. In: Liquid Fuels and Industrial Products from Renewable Resources. Proceedings of the Third Liquid Fuel Conference, 15-17 September, 1996, Nashville, Tennessee. $8 \mathrm{p}$.

20. Duffield, J.; Shapouri, H.; Graboski, M.; McCormick, R.; Wilson, R. US biodiesel development: new markets for conventional and genetically modified agricultural fats and oils. Economic Research Service/USDA. 31 p.

21. Pokrovskij, G. P. Fuel, lubricating oil and cooloing liquids (Топливо, смазочные материалы и охлаждающие жидкости). Moscow: Mashynostrojenyje, 1985. 195 p. (in Russian).

22. Lebedevas, S.; Vaicekauskas, A. Improvement of the parameters of maintenance of medium speed diesels applying the motor methods. Transport, Vol XIX, No 6, 2004, p. 252-261. ISSN 1648-4142.

23. Lebedevas, S. NO $\mathrm{NO}_{\mathrm{x}}$ emisijos mažinimas dyzelių išmetamosiose dujose taikant motorinius metodus. Transportas (Transport Engineering), Vol XVI, No 4, 2001, p. 32-43.
24. Knothe, G. Structure indices in FA chemistry. How relevant is the jodine value? USDA, ARS, National Center for Agricultural Utilization Research, Peoria, Illinois 61604. Paper No J10047 in JAOCS 79, 847-854 (September 2002). 8 p. 